\title{
$O$ diabo enquanto personagem literário em $O$ bom diabo de Monteiro Lobato e Belzebu.com, de Luis Fernando Veríssimo
}

\author{
Filipe Marchioro Pfützenreuter
}

\section{SciELO Books / SciELO Livros / SciELO Libros}

PFÜTZENREUTER, FM. O diabo enquanto personagem literário em O bom diabo de Monteiro Lobato e Belzebu.com, de Luis Fernando Veríssimo. In MAGALHÃES, ACM., et al., orgs. $O$ demoníaco na literatura [online]. Campina Grande: EDUEPB, 2012. pp. 63-76. ISBN 978-85-7879188-9. Available from SciELO Books <http://books.scielo.org>.

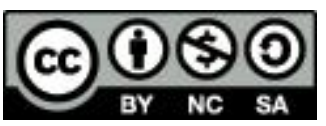

All the contents of this work, except where otherwise noted, is licensed under a Creative Commons Attribution-Non Commercial-ShareAlike 3.0 Unported.

Todo o conteúdo deste trabalho, exceto quando houver ressalva, é publicado sob a licença Creative Commons Atribuição Uso Não Comercial - Partilha nos Mesmos Termos 3.0 Não adaptada.

Todo el contenido de esta obra, excepto donde se indique lo contrario, está bajo licencia de la licencia Creative Commons Reconocimento-NoComercial-CompartirIgual 3.0 Unported. 


\section{O diabo enquanto personagem literário em $O$ bom diabo de Monteiro Lobato e Belzebu.com, de Luis Fernando Veríssimo}

Filipe Marchioro Pfützenreuter ${ }^{1}$ (UFSC/UNIBAVE)

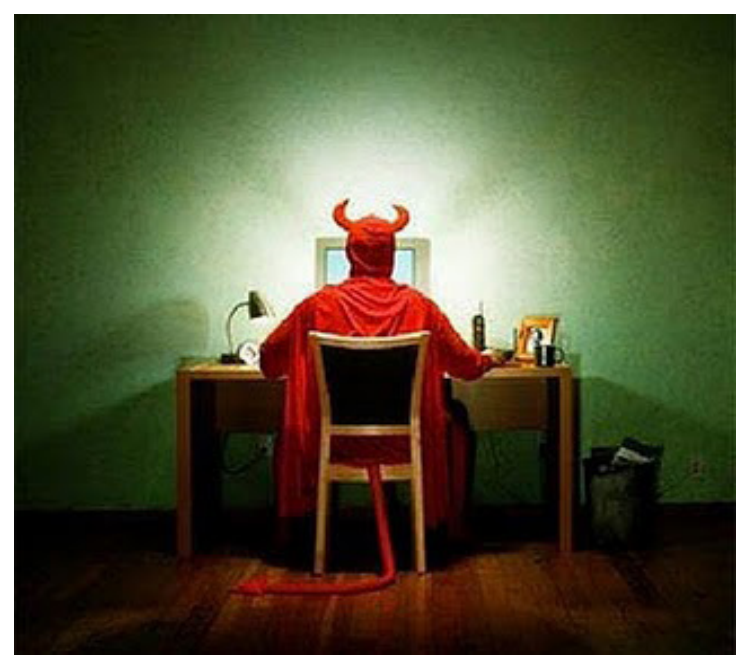

\section{Da tradição à ficção}

No discurso cristão, o Diabo aparece como a origem de todo o mal. Apartir de uma leitura do livro de Gênesis, ele se apresenta para Eva em forma de serpente e a induz a cometer o primeiro pecado da humanidade

1 Licenciado em Letras (Português/Inglês) pela Universidade do Extremo Sul Catarinense (UNESC). Mestre e Doutorando em Literatura pela Universidade Federal de Santa Catarina (UFSC). Professor do Centro Universitário Barriga Verde (UNIBAVE). E-mail: lipet0@yahoo.com.br. 
ao comer o fruto proibido. A serpente genesíaca, contudo, é apenas um dos personagens que compõem o Diabo no imaginário cristão. Além dela, é possível discernir pelo menos outros quatro: o bode expiatório, em Levítico; Satanás, no Livro de Jó; o Diabo, nos Evangelhos; e o Anjo Caído e seus heterônimos, no Apocalipse.

Segundo o livro de Gênesis, Deus criou o céu e a terra. Assim, todos os seres, as plantas, a luz, a escuridão, a água, enfim, tudo o que faz parte do mundo trata-se de uma criação divina. Esse processo todo levou seis dias. Até que no sétimo, tendo tudo concluído, Deus finalmente descansou.

A terra se transformou em um paraíso, conhecido como Éden, que abrigou os primeiros homens criados por Deus, ou melhor, o primeiro homem (Adão) e a primeira mulher (Eva) respectivamente. Dada a criação destes, não demorou muito para que o mal também tivesse origem. Tal acontecimento se deu a partir de uma árvore plantada no meio do jardim do Éden, a árvore do conhecimento do bem e do mal. Em relação a ela, Deus advertiu Adão: “De toda árvore do jardim comerás livremente, mas da árvore do conhecimento do bem e do mal não comerás; porque, no dia em que dela comeres, certamente morrerás." (Gn 2, 16-17).

Eis que surge a serpente para tentar Eva a desobedecer às ordens divinas. Com uma linguagem extremamente persuasiva, o animal convence a primeira mulher a comer o fruto proibido e, consequentemente, a cometer o primeiro pecado da humanidade:

A serpente era o mais astuto de todos os animais do campo que Javé Deus havia feito. Ela disse para a mulher: "É verdade que Deus disse que vocês não devem comer de nenhuma árvore do jardim?” A mulher respondeu para a serpente: "Nós podemos comer do fruto das árvores do jardim. Mas do fruto da árvore que está no meio do jardim, Deus disse: 'Vocês não comerão dele, nem o tocarão, do contrário vocês vão morrer'." Então a serpente disse para a mulher: "De modo nenhum vocês morrerão. Mas Deus sabe que, no dia em que vocês comerem o fruto, os olhos de vocês vão se abrir, e vocês se tornarão como deuses, conhecedores do bem e do mal". Então a mulher viu que a árvore tentava 
o apetite, era uma delícia para os olhos e desejável para adquirir discernimento. Pegou o fruto e o comeu; depois o deu também ao marido que estava com ela, e também ele comeu. Então abriram-se os olhos dos dois, e eles perceberam que estavam nus. Entrelaçaram folhas de figueira e fizeram tangas. (Gn 3,1-7)

Após o pecado original, homem e mulher recebem os primeiros castigos impostos por Deus. Ela passa a sofrer com as dores do parto e se torna submissa ao marido, enquanto ele é condenado a uma vida sofrida, trabalhando arduamente e sendo acometido por uma fome insaciável. Não obstante, o gênero humano é expulso do paraíso, tendo que, a partir de então, lutar para se redimir do pecado e reconquistar a paz. Enfim, é concebido o mundo dos homens e todas as mazelas nele existentes.

Na leitura cristã da história da criação do mundo, a serpente é o próprio Diabo e este é a origem de todo o mal. Esse raciocínio é amparado pala perspectiva de que Deus é uma entidade essencialmente benevolente e que os homens foram criados à sua imagem e semelhança: "Façamos o homem à nossa imagem e semelhança." (Gn 1, 26) Sendo assim, as criaturas não poderiam ser diferentes de seu criador, não sendo pela existência de uma força contrária, ou seja, pelo Diabo. Nessa perspectiva, Adão e Eva não teriam se interessado pelo fruto proibido se não tivessem sido tentados pela serpente.

Em Levítico, capítulo XVI, surge o segundo personagem que compõe o Diabo no imaginário cristão, trata-se do bode expiatório. No livro, Arão, que havia perdido seus dois filhos, foi incumbido de apresentar ao senhor um bode sobre o qual seriam lançados todos os pecados e impurezas dos israelitas. Em seguida, esse bode deveria ser apartado do rebanho e solto no deserto, de modo a possibilitar a purificação completa do povo.

Arão porá ambas as mãos sobre a cabeça do bode vivo e sobre ele confessará todas as iniquidades dos filhos de Israel, todas as suas transgressões e todos os seus pecados; e os porá sobre a cabeça do bode e enviá-lo-á ao deserto, pela mão de um homem à disposição para isso. (Lv 16, 21) 
Segundo Ferraz (2010, p. 18), há os que enxergam o bode expiatório como Cristo, pelo fato de ele carregar a culpa dos homens e ser morto no deserto, e há também aqueles que o enxergam como o Diabo, uma vez que fez os primeiros pais falharem, o primeiro Adão pecar. Embora a primeira leitura seja pertinente, é fato que os cristãos costumam usar a imagem do bode para representar o Diabo. Em sua imagem mais tradicional, ele se apresenta com corpo semelhante ao de um homem, mas dotado de barbicha e patas de bode. Sendo assim, não há como negar a influência do bode expiatório na composição do inimigo cristão.

O Livro de Jó, por sua vez, apresenta a história de um homem extremamente íntegro, um verdadeiro servo de Deus, mas que, a certa altura, é posto à prova pelo próprio Todo Poderoso. O fato acontece quando Deus elogia seu servo para Satanás e este argumenta que Jó precisaria ser privado de toda a sua riqueza para dar prova real de sua lealdade:

Perguntou ainda o Senhor a Satanás: Observaste o meu servo Jó? Porque ninguém há na terra semelhante a ele, homem íntegro e reto, temente a Deus e que se desvia do mal.

(...)

Estende, porém, a mão, e toca-lhe em tudo quanto tem, e verás se não blasfema contra ti e na tua face. (Jó 1, 8-11)

Ao longo da história, Jó perde seus filhos, sua fazenda e adoece. Em suma, é submetido a uma vida miserável. Entretanto, ele tem tudo restituído ao final, porque permanece fiel a Deus mesmo diante de todas as adversidades. Assim, ele recompõe sua fazenda, torna a enriquecer e tem outros sete filhos e três filhas.

Embora Satanás tenha contado com a autorização e cumplicidade divina para tentar Jó, para os cristãos, ele é o único responsável por todas as desgraças que assolam o rico fazendeiro. Mediante essa leitura, Satanás e o Diabo são compreendidos como a mesma pessoa, cujo objetivo é desvirtuar os homens de boa índole, intuindo privá-los da salvação no post-mortem.

O personagem designado pelo nome Diabo, contudo, vai aparecer pela primeira vez somente nos Evangelhos. O fato se dá quando Jesus, 
após ter sido batizado por João Batista, recolhe-se no deserto para jejuar por quarenta dias e quarenta noites, em preparação para o início da sua atividade messiânica. É nesse momento que o Diabo surge para instigá -lo a romper com seu pai e, consequentemente, para fazê-lo desistir de morrer em prol da redenção da humanidade:

Então o diabo disse a Jesus: "Se tu és Filho de Deus, manda que essa pedra se torne pão." Jesus respondeu: "A Escritura diz: 'Não só de pão vive o homem'." O diabo levou Jesus para o alto. Mostrou-lhe por um instante todos os reinos do mundo. E lhe disse: "Eu te darei todo o poder e riqueza desses reinos, porque tudo isso foi entregue a mim, e posso dá-lo a quem eu quiser. Portanto, se te ajoelhares diante de mim, tudo isso será teu." Jesus respondeu: "A Escritura diz: "Você adorará o Senhor seu Deus, e somente a ele servirá'." Depois o diabo levou Jesus a Jerusalém, colocou-o na parte mais alta do Templo. E lhe disse: "Se tu és Filho de Deus, jogate daqui para baixo. Porque a Escritura diz: 'Deus ordenará aos seus anjos a teu respeito, que te guardem com cuidado'. E mais ainda: Eles te levarão nas mãos, para que não tropeces em nenhuma pedra'." Mas Jesus respondeu: "A Escritura diz: 'Não tente o Senhor seu Deus'." Tendo esgotado todas as formas de tentação, o diabo se afastou de Jesus, para voltar no tempo oportuno. (Lc 4, 3-13)

Conforme pode se observar no texto do evangelista Lucas, assim como a serpente em Gênesis e Satanás no Livro de Jó, o Diabo do Novo Testamento aparece como um grande tentador. Nem mesmo Cristo, o filho de Deus, está salvo de suas investidas. Data a semelhança, não haveria como deixar de associar os personagens desses três livros distintos.

O Apocalipse, por sua vez, é o livro responsável por justificar definitivamente a conexão estabelecida pelos cristãos entre os personagens de Gênesis, Levítico, Jó e dos Evangelhos. É no último livro bíblico que o leitor finalmente tem acesso à biografia completa do Diabo. Este foi originalmente um anjo do Senhor, mas que foi expulso dos Céus 
após liderar uma rebelião contra ele, daí a origem da designação Anjo Caído.

Aconteceu então uma batalha no céu: Miguel e seus Anjos guerrearam contra o Dragão. O Dragão batalhou juntamente com os seus Anjos, mas foi derrotado, e no céu não ouve mais lugar para eles. Esse grande Dragão é a antiga Serpente, é o chamado Diabo ou Satanás. É aquele que seduz todos os habitantes da terra. O Dragão foi expulso para a terra, e os Anjos do Dragão foram expulsos com ele. (Ap 12, 7-9)

Como pode se observar acima, São João coloca de forma bem explícita para o leitor que o Dragão, a Serpente, Satanás e o Diabo são manifestações de uma mesma entidade. Além disso, o Diabo é claramente apontado como o responsável por todo o mal. Em uma linguagem metafórica, o texto coloca o Diabo como o responsável pelo castigo de Eva (as dores do parto), acusa-o de tentar promover a morte do menino Jesus, atribui a ele a culpa pelos pecados dos homens e, por conseguinte, pelas mazelas mundanas:

Apareceu no céu um grande sinal: uma Mulher vestida com o sol, tendo a lua debaixo dos pés, e sobre a cabeça uma coroa de doze estrelas. Estava grávida e gritava, entre as dores do parto, atormentada para dar à luz. Apareceu, então, outro sinal no céu: um grande Dragão, cor de fogo. Tinha sete cabeças e dez chifres. Sobre as cabeças sete diademas. Com a cauda ele varria para a terra parte das estrelas do céu, jogando-as sobre a terra. O Dragão colocou-se diante da Mulher que estava para dar à luz, pronto para the devorar o Filho, logo que ele nascesse. Nasceu o Filho da Mulher. Era menino homem. Nasceu para governar todas as nações com cetro de ferro. Mas o filho foi levado para junto de Deus e de seu trono. (Ap 12, 1-5)

Ainda em relação ao Apocalipse, vale pontuar que neste livro também se encontra uma descrição física do Diabo bem detalhada, pelo menos em relação a uma das suas formas: sete cabeças, dez chifres, diademas sobre 
as cabeças e calda. A partir dessas características, o imaginário popular e a arte deram origem a muitas outras imagens para ele, sendo que a mais recorrente é, sem dúvida, a de um ser horrendo, de pele vermelha ou escura, com chifres, rabo em forma de seta, barbicha e patas de bode, cheirando a enxofre e armado com um tridente.

A leitura da Bíblia enquanto obra literária tem sido cada vez mais frequente em tempos modernos. A liberdade religiosa alavancada pelo Iluminismo tirou da igreja o monopólio sobre o livro, ou melhor, sobre a compilação de livros mais vendida do mundo, fazendo com que ela deixasse de servir exclusivamente ao panfletismo religioso.

Não é por se tratar de literatura, ou também de literatura, que a Bíblia se torna menos fascinante. O que se observa é que ela não é menos fonte de provisões literárias do que é de provisões religiosas, tanto que Sabino (1995, p. 15) afirma que, somente no século XIX, foram publicados mais de sessenta mil livros a respeito de Jesus Cristo, o protagonista do Novo Testamento. Com relação ao Cristo literário, Küng assume o seguinte posicionamento:

Um escritor certamente não almeja delinear uma imagem impessoal, histórica e objetiva para Jesus, contendo todos os pormenores relevantes. O que ele procura é trazer à tona e enfatizar um aspecto que pense ser importante, para reunir um número de temas, para clarear um ponto específico. O estilo é atingido pela ênfase subjetiva. $\mathrm{O}$ escritor, como tal, não está interessado em investigação historicamente exata, mas na visão das muitas imagens existentes de Cristo, não apenas na dos concílios, mas na dos devotos e apaixonados, dos teólogos e pintores, e também dos escritores. É o teólogo que deve responder à questão: que retrato de Cristo é verdadeiro? A qual dos retratos existentes devemos nos agarrar na prática? (KÜNG, 1976, p. 143, tradução nossa $)^{2}$

2 A writer certainly does not want to draw an objective, historically accurate picture of Jesus, containing all the relevant details. What he seeks is to bring out and emphasize one aspect which he thinks important, to bring together a number of themes, to throw a clearer light on one point. Style is achieved by subject emphasis. The writer as such is not 
A afirmação de Küng em relação ao Cristo literário também vale para os demais personagens bíblicos. Da mesma forma que o escritor não objetiva resgatar o Cristo histórico, ele também não objetiva recriar um diabo teologicamente correto. O que deseja com tais personagens é inseri-los segundo os interesses de sua obra, e não distorcer sua obra de modo a adequá-la aos personagens herdados do outro contexto.

Segundo Ferraz (2007, p. 235), o Diabo está presente no mundo medieval, ocidental e também no mundo das crianças, mostrando-se excelente motivo e tema da boa literatura. Ainda segundo a autora, ele representa o maior fantasma coletivo do Ocidente e, sem ele, a literatura, a teologia e a própria humanidade não seriam as mesmas. Contudo, na Literatura Pós-Iluminista, nem sempre coube ao Diabo o papel de vilão ou antagonista, pelo menos não como se prega ao longo dos séculos no meio cristão. Conforme afirma Souza (2007, p. 8), "no século XIX, a história divina contada nos textos bíblicos começa a receber interpretações heterodoxas pela História, Filosofia e Literatura."

A presença constante do Diabo na Literatura Pós-Iluminista, seja assumindo o papel de herói em um extremo, seja assumindo o papel de vilão em outro, deu margem a uma seara de estudos literários buscando compreender o fenômeno. Em relação a O Evangelho Segundo Jesus Cristo, de José Saramago, por exemplo, Pinheiro (2007, p. 8) lembra que ele "já foi dissecado pela crítica de todo o mundo e questionado até mesmo pelo governo e pela Igreja." No entanto, esses estudos preocuparam-se mormente com as obras literárias acessadas pelo público adulto, olvidando-se daquelas que são lidas por crianças e jovens.

Vale destacar que, no presente artigo, utilizar-se-á o termo Literatura Infanto-Juvenil com o único intuído de designar um grupo de obras que é direcionado ou lido mais especificamente pelo público dessa faixa etária. O uso desse termo não implica, de forma nenhuma, em segregação operada por critérios qualitativos. Nesse sentido, assume-se a concepção de Ferraz (2007, p. 222), a qual não concorda com nenhum tipo

interested in historically exact investigation. But in view of the many Christ images not only of the councils, of the devout and the enthusiasts, of theologians and painters, and also of the writers, it is the theologian who must answer the question: which portrait of Christ is the true one? To which of them should we cling in practice? (KÜNG, 1976, p. 143) 
de divisão terminológica para a Literatura. Para a autora, esta arte deve interessar ao leitor em geral, seja ele criança, adulto, mulher, branco ou negro. Do contrário, não se trata de Literatura.

Dadas as considerações acima, o presente artigo traz na sequência uma análise do processo de composição do personagem Diabo em duas obras da Literatura Infanto-Juvenil brasileira, atentando para os contrastes e semelhanças entre o arquétipo cristão e o modo como ele ressurge nos escritos de Monteiro Lobato e Luis Fernando Veríssimo.

\section{O Diabo segundo Monteiro Lobato}

José Bento Monteiro Lobato é possivelmente um dos maiores representas da Literatura para crianças no Brasil. O paulista de Taubaté, nascido em 1882 e falecido em 1948, deixou um legado de obras que, até hoje, são lidas por crianças de todo o país e também do exterior. Dentre elas, destacam-se principalmente as que integram a coleção Sítio do Picapau Amarelo, como Reinações de Narizinho (1931), Memórias de Emília (1936) e Histórias de Tia Nastácia (1937). Nesta está incluído o conto O Bom Diabo, que reflete nitidamente a personalidade anticonvencional do artista.

O Bom Diabo narra a história de um príncipe que estava fadado a morrer enforcado, mas que, por intervenção do Diabo, conseguiu livrar-se desse trágico fim. Ao tomar conhecimento de seu destino por intermédio da mãe, o menino decide se afastar da família, entendendo que a morte longe desta seria mais facilmente superada. Então, ele corre por cidades e reinos até que se depara com uma capela de São Miguel, na qual havia a imagem deste santo e do Diabo. O príncipe decide restaurar a capela e as imagens, dando ordens expressas para que os obreiros também contemplassem o Diabo, uma vez que este havia sido inicialmente deixado de lado. Findada a obra, pintados santo e Diabo, ele pede abrigo na casa de uma velha a qual, observando-o contar o dinheiro que ainda lhe restava, denuncia-o para o rei sob a acusação de roubo. Eis que o príncipe é condenado à forca. No entanto, ao tomar conhecimento do caso, o Diabo vai à casa da velha e a obriga a desmentir a história, conseguindo, assim, salvar o príncipe do seu destino indesejável. Tudo isso em gratidão àquele que lhe tratou de igual para igual em relação ao santo. Aquele que, contra tudo e contra todos, também assegurou que sua imagem fosse restaurada e pintada com dignidade. 
Como pode se observar, não é possível aferir nenhum atributo maligno ao Diabo de Lobato. Pelo contrário, a sua atitude em relação ao príncipe é mais do que benevolente. Ela também revela um Diabo que possui gratidão, que age desinteressadamente e que tem sede por justiça. Sua gratidão é demonstrada quando ele abandona a capela às pressas ao saber que o condenado à morte na forca era aquele que havia recuperado sua imagem. O seu agir desinteressadamente pode ser observado quando ele não cobra nada do príncipe por ter lhe salvado a vida. E a sua sede por justiça é confirmada quando ele, além de salvar o príncipe, também obriga a velha a confessar a sua mentira ao rei, sendo que este a condena a restituir o dinheiro ao seu verdadeiro dono e a ir para a forca:

...Terminado o caso, o moço partiu novamente a correr mundo.

Pelo caminho encontrou um fidalgo, ao qual contou tudo.

O fidalgo disse:

- E não sabes quem te valeu?

- Não sei de nada - respondeu o príncipe.

- Pois fica sabendo que foi o diabo da capelinha de S. Miguel, e esse diabo sou eu. No dia em que iam enforcar-te, S. Miguel me contou tudo. Montei num cavalo e voei à casa da velha; agarrei-a e levei-a ao rei, para que tudo se esclarecesse.

- E a que devo eu tanta bondade? - perguntou o príncipe.

- Ah! - exclamou o diabo, rindo-se. - Tudo deves àquele bocadinho de tinta que mandaste aplicar sobre minha figura. Agora estás livre da má sina, porque a velha vai ser enforcada em teu lugar. Podes voltar sossegadamente ao reino de teu pai, que nada mais te acontecerá. (LOBATO, 1995, p. 34)

Ainda que o Diabo de Lobato seja muito parecido com o que tradicionalmente se imagina de Deus, em um atributo aquele se difere deste: o personagem diabólico não é onipresente. Ele teve que recorrer a São Miguel para tomar conhecimento de como se deu a restauração de sua imagem e quem foi que a propiciou. Outro detalhe é que não há, no conto lobatiano, nenhuma descrição física do Diabo, conferindo, assim, liberdade ao leitor para imaginá-la. 
Por fim, é possível se fazer uma analogia entre o conto e a história do próprio autor. A partir de 1931, após retornar dos Estados Unidos, Monteiro Lobato foi perseguido, preso e criticado por divulgar a existência de petróleo no Brasil. Na época, havia interesse oficial em dizer o contrário e Lobato acreditava que o povo precisava usufruir desse recurso natural para conseguir uma vida mais digna. Sendo assim, parece que a dedicação do autor à Literatura para crianças pode também ser uma manifestação do seu desgosto para com o público adulto e a censura oriunda do mesmo.

No final do conto, a narradora, Tia Nastácia, confessa não acreditar nesse Diabo bonzinho presente na história, tratando esta como mera ficção e possibilidade de entretenimento. Emília, por sua vez, sai em defesa do Diabo. Para tanto, ela associa o personagem ao melhor amigo do homem em função do termo cão, que Tia Nastácia usa para se referir a ele:

Narizinho confessou que gostava muito das histórias com o diabo dentro, e disse que todas elas confirmavam o dito popular de que o diabo não é tão feio como o pintam.

- Credo! - exclamou tia Nastácia fazendo três benzeduras. - Como é que uma menina de boa educação tem coragem de dizer isso do canhoto?

Narizinho arregalou os olhos.

- Como? É boa! Pois você mesma não acaba de contar a história dum diabo bom?

- Mas isso é história, menina. História é mentira. O "cão" é "cão". Não muda de ruindade.

- Se o cão é cão, viva o diabo! - gritou Emília. Não há animal melhor, nem mais nobre que o cão. Chamar ao diabo cão é fazer-lhe o maior elogio possível. (LOBATO, 1995, p. 34, negrito nosso)

Através da personagem Emília, a boneca que não tem papas na língua, Lobato parece externar tudo aquilo que lhe é censurado pelos homens, bem como contestar as verdades socialmente aceitas. Assim ele o faz em O Bom Diabo, na medida em que ignora a imagem tradicional do personagem enquanto ser maligno e o remonta às avessas, como um ser tão benevolente quanto Deus. 


\section{O Diabo segundo Luis Fernando Veríssimo}

Luis Fernando Veríssimo, nascido em Porto Alegre no ano de 1936, é nacionalmente conhecido por suas crônicas e textos bem-humorados. Seus escritos são bastante difundidos entre os jovens. A coletânea Comédias para se ler na escola foi inclusive uma das obras contempladas pelo vestibular da Universidade Federal de Santa Catarina. Outra das suas coletâneas é Orgias, publicada em 2005. É neste livro que está inserida a crônica Belzebu.com, a qual aborda uma negociação virtual entre o narrador e o inimigo cristão.

A estória tem início com o narrador recebendo um e-mail do Diabo, no qual este dizia estar procurando pessoas dispostas a trocarem suas almas por aquilo que desejassem, uma única coisa. Interessado no negócio, o narrador tem dificuldades para decidir o que desejaria. Inicialmente, pensa na Vera Fischer, depois em uma vitória do Internacional no campeonato e, por fim, acaba optando por um pedido que, ao seu ver, acabaria beneficiando um número maior de pessoas: a transformação do Brasil em um país escandinavo.

A decisão vem após o narrador pensar nos problemas sociais e culturais brasileiros que seriam solucionados com tal transformação: a irresponsabilidade das pessoas, a indecência hipócrita da sociedade, os crimes impunes. Eis uma crítica presente em Belzebu.com aos padrões comportamentais do brasileiro e a problemas sociais que comprometem o desenvolvimento do país.

Quanto ao Diabo de Veríssimo, a grande novidade fica por conta da uma modernização do personagem, posto que a negociação da alma é feita por e-mail. Um detalhe interessante dessa negociação é que o Diabo não precisa fazer muito esforço para convencer o narrador a trocar sua alma, é este quem toma toda a iniciativa. Por outro lado, seu esforço se concentra em fazê-lo pensar em outra moeda de troca, ou seja, em dissuadi-lo da ideia de transformar o Brasil em um país escandinavo. Para tanto, ele coloca seu interlocutor a par das dificuldades que viriam com tal mudança, advertindo que as pessoas precisariam se adaptar à nova língua, à moeda, ao frio, aos hábitos diferentes. Além disso, alerta para os atributos positivos dos brasileiros que seriam deixados para trás: a alegria, a simpatia, a criatividade. Desse modo, fica evidente o interesse do Diabo em conservar as mazelas que afligem o povo brasileiro, portanto, diferentemente do Diabo de Monteiro Lobato, o personagem de Veríssimo conserva a malevolência do seu arquétipo cristão. 
Outra novidade em relação ao Diabo de Veríssimo é que ele não exige que os ganhos da negociação sejam todos para ele, algo inimaginável pelos cristãos mais ortodoxos para um ser que se atreveu a tentar o próprio filho de Deus. Em sua última tentativa de dissuadir seu interlocutor, o Diabo de Veríssimo sugere tornar o Brasil escandinavo durante o expediente e fazê-lo permanecer brasileiro no seu encerramento, ou seja, ele se propõe a resolver os problemas do Brasil parcialmente. Essa opção certamente não excluiria a bebedeira, as festas, o adultério, enfim, situações que potencialmente geram desordem mesmo sendo fora do âmbito profissional. Por fim, o narrador não aceita a proposta, mas ela serve para levá-lo a postergar a mudança do Brasil para depois do carnaval, de modo que ele pudesse a aproveitar a festa popular por uma última vez.

Com Belzebu.com, Luis Fernando Veríssimo conserva a característica malevolente e a condição de tentador do Diabo, mas também inova ao modernizar e nacionalizar a história do personagem. A modernidade reside no fato de o Diabo fazer uso do ambiente virtual para realizar os seus negócios. É justamente por se tratar de um ambiente virtual, que o leitor não conta com nenhum tipo de descrição física. Já a nacionalização está presente na abordagem dos problemas do Brasil e do jeito de ser do brasileiro, o que fica ainda mais evidente no desfecho da história, quando o narrador posterga a mudança do Brasil para depois do carnaval, ou seja, deixa a resolução do problema para em segundo momento.

As duas obras analisadas, O Bom Diabo e Belzebu.com, demonstram uma despreocupação por parte de seus escritores em seguirem os ditames da tradição religiosa ao inserirem o Diabo como personagem em suas obras. Pelo contrário, cada escritor recria o personagem bíblico à sua maneira e de acordo com a proposta de sua obra. Monteiro Lobato engendra um Diabo benevolente, desinteressado e justiceiro, indo abertamente contra a concepção cristã do personagem. Luis Fernando Veríssimo, por sua vez, conserva a imagem do Diabo enquanto tentador. Contudo, seu personagem é um Diabo moderno, que faz uso da internet para negociar almas. Além disso, o personagem de Veríssimo é um negociador, uma vez que aceita abrir mão de um pouco do seu lucro, algo que contraria a intransigência do Diabo bíblico, o tentador de Eva, Jó e Jesus. O Bom Diabo e Belzebu.com, obras que são acessadas pelo público infanto-juvenil brasileiro, o Diabo não é tratado como coisa séria. Pelo contrário, ele é retirado da esfera do sagrado para entreter o leitor, apresentando-se sob formas que demonstram uma total despreocupação com a ortodoxia religiosa: um Diabo às avessas (benevolente), no caso de Lobato; e um Diabo modernizado, no caso de Veríssimo. 


\section{Bibliografia}

BÍBLIA. Português. Edição pastoral. São Paulo: Paulinas, 1990. 1631p.

BÍBLIA. Português. Bíblia de estudo Almeida. Barueri: Sociedade Bíblica do Brasil, 2006. 1728p.

FERRAZ, Salma. O Diabo na literatura para crianças. Linguagens: Revista de Letras, Artes e Comunicação, Blumenau, v. 1, n. 3, p.220-238, 2007. Disponível em: <http://proxy.furb.br/ojs/index.php/linguagens/issue/ view/127/showToc $>$. Acesso em: 01 nov. 2010.

KÜNG, Hans. On being a christian. Tradução de: Edward Quinn. New York: Doubleday, 1976.

LOBATO, Monteiro. O Bom Diabo. In: LOBATO, Monteiro. Histórias de Tia Nastácia. São Paulo: Brasiliense, 1995. p. 33-34. Ilustrações e capa de Manoel Victor.

PINHEIRO, Vanessa Neves Riambau. O trágico e o demoníaco em “O Evangelho Segundo Jesus Cristo", de José Saramago. 2007. 95 f. Dissertação (Mestrado) - Curso de Pós-graduação em Literaturas Brasileira, Portuguesa e Luso-africanas, Departamento de Pós-graduação em Letras, Universidade Federal do Rio Grande do Sul, Porto Alegre, 2007. Disponível em: <http://www.lume.ufrgs.br/handle/10183/10789>. Acesso em: 10 jun. 2010.

SOUZA, Ronaldo Ventura. O Jesus de Saramago e a Literatura que revisita Cristo. 2007. 156 f. Dissertação (Mestre) - Curso de Pós-graduação em Literatura Portuguesa, Departamento de Letras Clássicas e Vernáculas, Universidade de São Paulo, São Paulo, 2007. Disponível em: < http://www. teses.usp.br/>. Acesso em: 10 jun. 2010.

VERÍSSIMO, Luis Fernando. Belzebu.com. In: VERÍSSIMO, Luis Fernando. Orgias. Rio de Janeiro: Objetiva, 2005. p. 136.

\section{Imagens:}

http://noticias.gospelmais.com.br/exorcistas-internet-facilita-trabalhodiabo-18378.html 